\title{
Intermolecular interaction analyses on SARS-CoV-2 receptor binding domain and human angiotensin- converting enzyme 2 receptor- blocking antibody/peptide using fragment molecular orbital calculation
}

Kazuki Watanabe ${ }^{1}$, Chiduru Watanabe ${ }^{2,3,{ }^{*}}$, Teruki Honma ${ }^{2}$, Yu-Shi Tian ${ }^{1}$, Yusuke Kawashima $^{4}$, Norihito Kawashita ${ }^{5}$, Tatsuya Takagi ${ }^{1, *}$, and Kaori Fukuzawa ${ }^{4,6, *}$

${ }^{1}$ Graduate School of Pharmaceutical Sciences, Osaka University, 1-6 Yamadaoka, Suita City, Osaka 565-0871, Japan

${ }^{2}$ Center for Biosystems Dynamics Research, RIKEN, 1-7-22 Suehiro-cho, Tsurumi-ku, Yokohama, Kanagawa 230-0045, Japan

${ }^{3}$ JST PRESTO, 4-1-8, Honcho, Kawaguchi, Saitama 332-0012, Japan

${ }^{4}$ School of Pharmacy and Pharmaceutical Sciences, Hoshi University, 2-4-41 Ebara, Shinagawa-ku, Tokyo 142-8501, Japan

${ }^{5}$ Graduate School of Science and Engineering Research, Kindai University, 3-4-1 Kowakae, Higashiosaka City, Osaka 577-8502, Japan 
${ }^{6}$ Department of Biomolecular Engineering, Graduate School of Engineering, Tohoku University, 6-6-11 Aoba, Aramaki, Aoba-ku, Sendai 980-8579, Japan

Corresponding Authors

Chiduru Watanabe

Center for Biosystems Dynamics Research, RIKEN, 1-7-22 Suehiro-cho, Tsurumi-ku, Yokohama, Kanagawa 230-0045, Japan

Chiduru.watanabe@riken.jp

Tatsuya Takagi

Graduate School of Pharmaceutical Sciences, Osaka University, 1-6 Yamadaoka, Suita City, Osaka 565-0871, Japan

ttakagi@phs.osaka-u.ac.jp

Kaori Fukuzawa

School of Pharmacy and Pharmaceutical Sciences, Hoshi University, 2-4-41 Ebara, Shinagawa-ku, Tokyo 142-8501, Japan

k-fukuzawa@hoshi.ac.jp 


\section{Abstract}

The spike glycoprotein (S-protein) mediates SARS-CoV-2 entry via intermolecular interaction with human angiotensin-converting enzyme 2 (hACE2). The receptor-binding domain (RBD) of the S-protein has been considered critical for this interaction and acts as the target of numerous neutralizing antibodies and antiviral peptides. This study used the fragment molecular orbital (FMO) method to analyze the interactions between RBD and antibodies/peptides and extracted crucial residues that can be used to epitopes. The interactions evaluated as inter-fragment interaction energy (IFIE) values between the RBD and 12 antibodies/peptides showed a fairly good correlation with the experimental activity $\mathrm{pIC}_{50}\left(R^{2}=0.540\right)$. Nine residues $(\mathrm{T} 415, \mathrm{~K} 417, \mathrm{Y} 421, \mathrm{~F} 456, \mathrm{~A} 475, \mathrm{~F} 486, \mathrm{~N} 487$, N501, and Y505) were confirmed as crucial. Pair interaction energy decomposition analyses (PIEDA) showed that hydrogen bonds, electrostatic interactions, and $\pi$-orbital interactions are important. Our results provide essential information for understanding SARS-CoV-2-antibodies/peptide binding and may play roles in future antibody/antiviral drug design. 
TOC Graphic

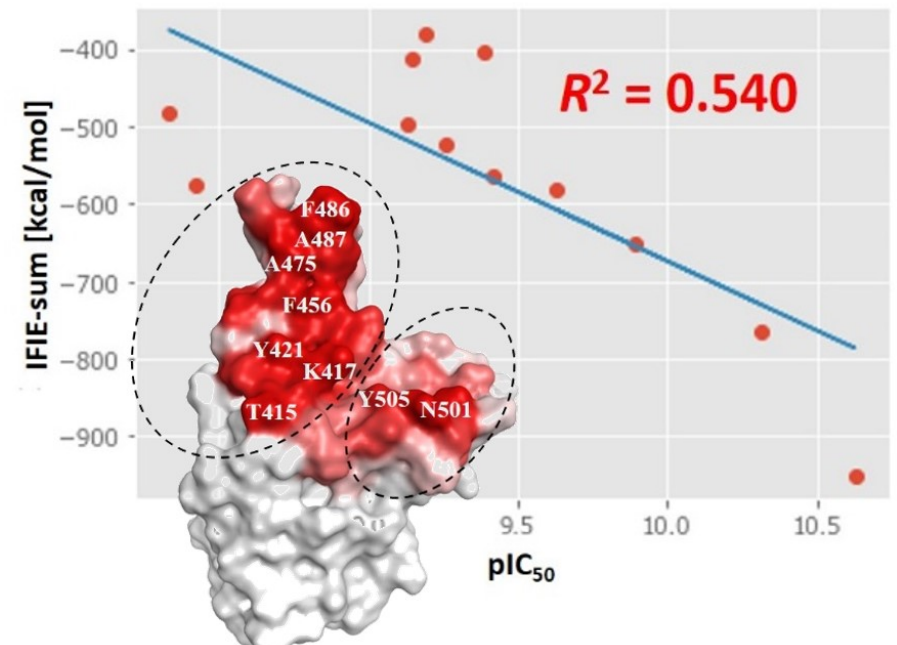

Epitopes and binding-affinities between SARS-CoV-2 S-protein and ACE2-blocking antibodies 
Coronavirus disease 2019 (COVID-19) caused by severe acute respiratory syndrome coronavirus 2 (SARS-CoV-2) has become an urgent health concern ${ }^{1,2}$. As of January 21, approximately 110 million infections and over 2.4 million deaths were confirmed worldwide $^{3}$. Recently, the vaccines Tozinameran ${ }^{4,5}$ and mRNA-1273 developed by Pfizer-BioNTech and Moderna ${ }^{6,7}$, respectively, have been approved for emergency use by the Food and Drug Administration (FDA), which raises expectations for the convergence of COVID-19. However, herd immunity via a high percentage of the global population being vaccinated requires more time. Recently, highly infectious variants of SARS-CoV-2 were reported in the UK, South Africa, Brazil, and other countries ${ }^{8-10}$. Although there is no evidence showing that these variants can increase viral pathogenicity, the effectiveness of underused vaccines may become questionable for specific mutations. Therefore, combating this virus may continue for a long time, and more candidates for drugs and vaccines are urgently needed.

SARS-CoV-2 belongs to betacoronaviruses, which comprise the spike, envelope, membrane, and nucleocapsid as structural proteins ${ }^{11}$. Among the structural proteins, the glycoprotein (S-protein) mediates entry into the host cell via intermolecular interaction with human angiotensin-converting enzyme $2(\mathrm{hACE} 2)^{12}$ at its receptor-binding domain 
$(\mathrm{RBD})^{13-16}$, making it a promising target for both antivirals and neutralizing antibodies. To date, numerous antibodies targeting the RBD of S-proteins have been reported ${ }^{17-26}$. These antibodies can be classified into four categories based on their binding sites (Figure 1a) ${ }^{22}$. Among them, antibodies that target RBD-hACE2 interaction sites as epitopes are considered particularly crucial, owing to the exceptions for the direct interruption of Sprotein-hACE2 binding. Understanding the detailed binding modes of the RBD with currently reported antibodies/peptides ${ }^{27,28}$ can provide useful information for the design of more potent neutralizing antibodies and antiviral drug candidates.

The fragment molecular orbital (FMO) method is an $a b$ initio quantum chemical calculation method ${ }^{29-31}$ and has recently been applied to quantitatively and accurately evaluate molecular interactions ${ }^{32-41}$. Our group comprehensively performed FMO calculations on each target of COVID-19-related proteins, registered the results in the FMO database (FMODB) $)^{42-44}$, and released the data for use by other researchers. Interaction analyses between S-protein and hACE2 or B38 Fab antibodies using the FMO method have been reported ${ }^{45-47}$. This study focused on 12 antibodies/peptides (LCB1 ${ }^{27}$, $\mathrm{LCB}^{27}{ }^{27}, \mathrm{C} 105^{23}, \mathrm{COVA} 2-04^{21}, \mathrm{BD}-604^{26}, \mathrm{CB}^{17}, \mathrm{~B} 38^{17}, \mathrm{BD}-629^{26}, \mathrm{C} 102^{22}, \mathrm{CC} 12.3^{19}$, $\mathrm{CC} 12.1^{19}$, and $\mathrm{CV} 30^{17}$ ) and analyzed the interactions between these antibodies/peptides 
and the RBD using the FMO method. To obtain more useful information for rational antibody design, we further estimated the importance of amino acid residues and regions in the RBD for antibody/peptide binding.

The complex structural data of the RBD and antibodies/peptides were obtained from PDB, and preparations were conducted (see Supporting Information). Subsequently, the FMO calculation at the MP2/6-31G*48,49 level was conducted using the ABINIT-MP $\operatorname{program}^{50-52}$. The FMO calculation results were registered in $\mathrm{FMODB}^{42-44}$ (Table S1). These data can be downloaded by users from the FMODB based on an FMODB ID or PDB ID, IFIE/PIEDA analysis is also easily possible on the web interface. The interfragment interaction energy (IFIE) values of the complexes were obtained. The IFIE values were further decomposed by the pair interaction energy decomposition analysis (PIEDA) calculation into four components: electrostatic (ES), exchange repulsion (EX), charge transfer with mixed terms $(\mathrm{CT}+\mathrm{mix})$, and dispersion $(\mathrm{DI})^{53,54}$.

The IFIE-sum, which was the sum of IFIEs between RBD and antibodies/peptides, indicated that the estimated binding interaction energies between RBD and antibodies/peptides showed a fairly good correlation with the experimental inhibitory activities $\left(\mathrm{pIC}_{50}\right)$ of the antibodies/peptides $\left(R^{2}=0.540\right.$, Figure 1c, Table S1 $)$. A stronger 
IFIE-sum estimated from FMO would indicate higher antiviral activities of antibodies/peptides targeting RBD. 

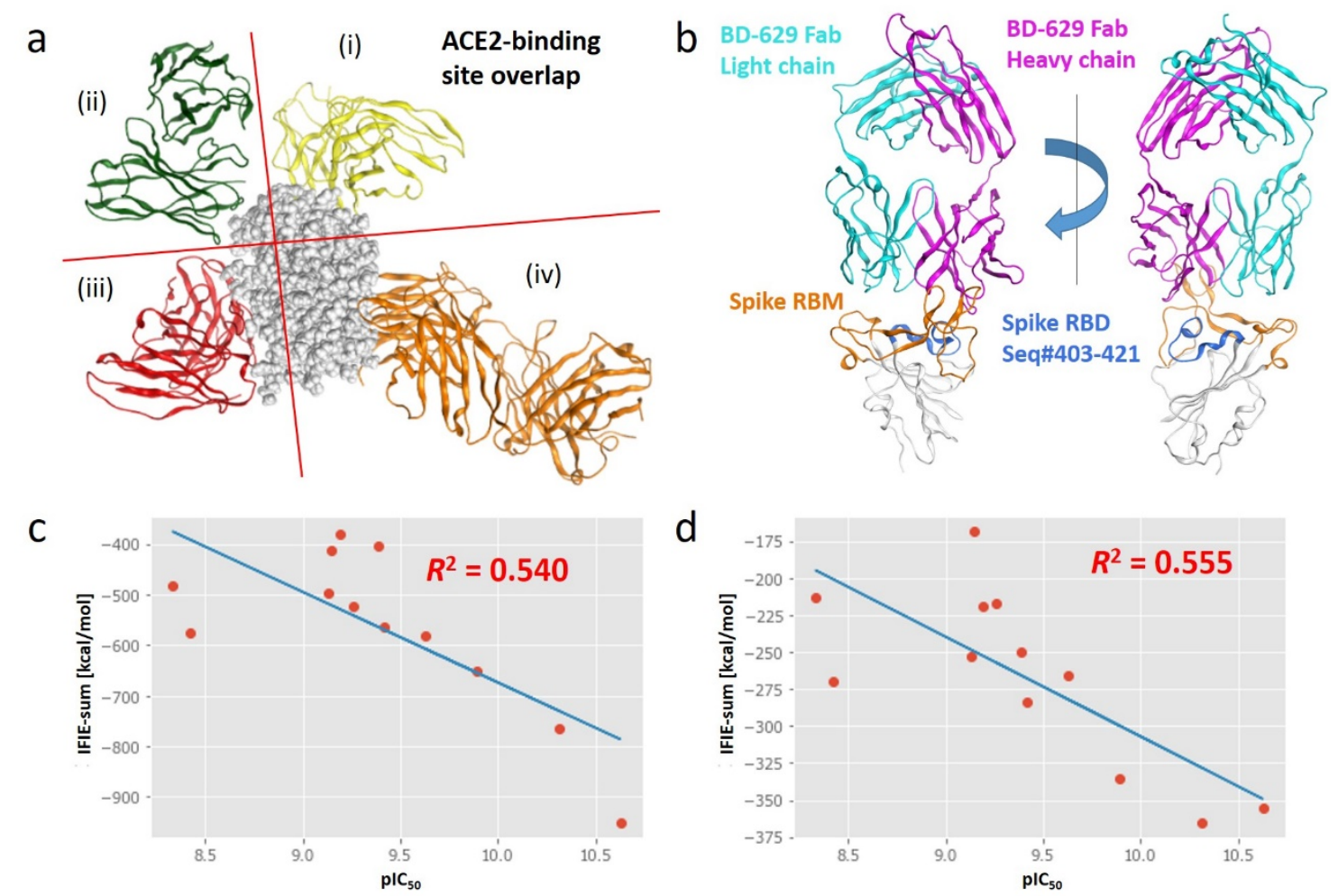

Figure 1. (a) Four binding sites of antibodies on the RBD (PDB IDs: 6XCM (i), 7CHH (ii), 6WPS (iii), and 6YLA (iv)). (b) Location of critical regions on the RBD from the view of antibodies (PDB ID: 7CH5) (c). Correlation between IFIE-sum and experimental activities $\left(\mathrm{pIC}_{50}\right)(\mathrm{d})$. Correlation between the IFIE-sum obtained from the nine key residues (T415, K417, Y421, F456, A475, F486, N487, N501, and Y505) on the RBD and experimental activities $\left(\mathrm{pIC}_{50}\right)$.

We further investigated the importance of the RBD-antibody/peptide binding region, especially the interface residues. First, the antibody/peptide binding regions were selected per the EX, CT+mix, and DI value except $\mathrm{ES}^{53,54}$. These values are only non-zero when close interactions can be detected. The residues binding the antibody/peptide were in two regions: Seq\# 403-421 and the receptor-binding motif (RBM, Seq\# 438-506) ${ }^{55}$. The latter RBM is the major binding site of hACE2. The steric location of these two regions 
of one structure (PDB ID 7CH5) is shown in Figure 1b. These two regions are located at the interaction interface with the RBD-BD-629 Fab antibody and nearby regions. Previous research on the interaction between SARS-CoV-2 S-protein RBD and ACE2 with FMO calculation ${ }^{46}$ also showed that the interaction sites of hACE2 on RBD could be concentrated in these two regions.

The contributions of residues in these two regions to the RBD-antibody/peptide interactions were investigated using the ratio of the IFIE-sum (Table S2). The ratio of IFIE-sum of region 1 (Seq\# 403-421) to the total IFIE-sum is about 40-50\% (average $47.3 \%)$. Although the number of residues in the region is small (19), the contribution is high. Similarly, the ratio of the IFIE-sum of region 2 (RBM) to the total IFIE-sum is approximately $40 \%-60 \%$ (average $53.4 \%$ ), and it exceeds $50 \%$ in 7 of the 12 structures treated in this study, indicating its high contribution. From the above, regions 1 and 2 play an important role in the RBD-antibody/peptide interaction in these complexes.

Next, to reveal important residues for molecular recognition between the RBD and antibody/peptide, we selected important residues meeting the criteria ${ }^{46}$ from these two regions for all complexes. For any ES, CT + mix, and DI components, the residues with interaction energies less than $-3 \mathrm{kcal} / \mathrm{mol}$ were considered important (Table S3). The 
frequencies for the selected residues are listed in Table S4 based on energy components,

Figure 2 shows the RBD with a color gradation of the frequency on the molecular surface. 

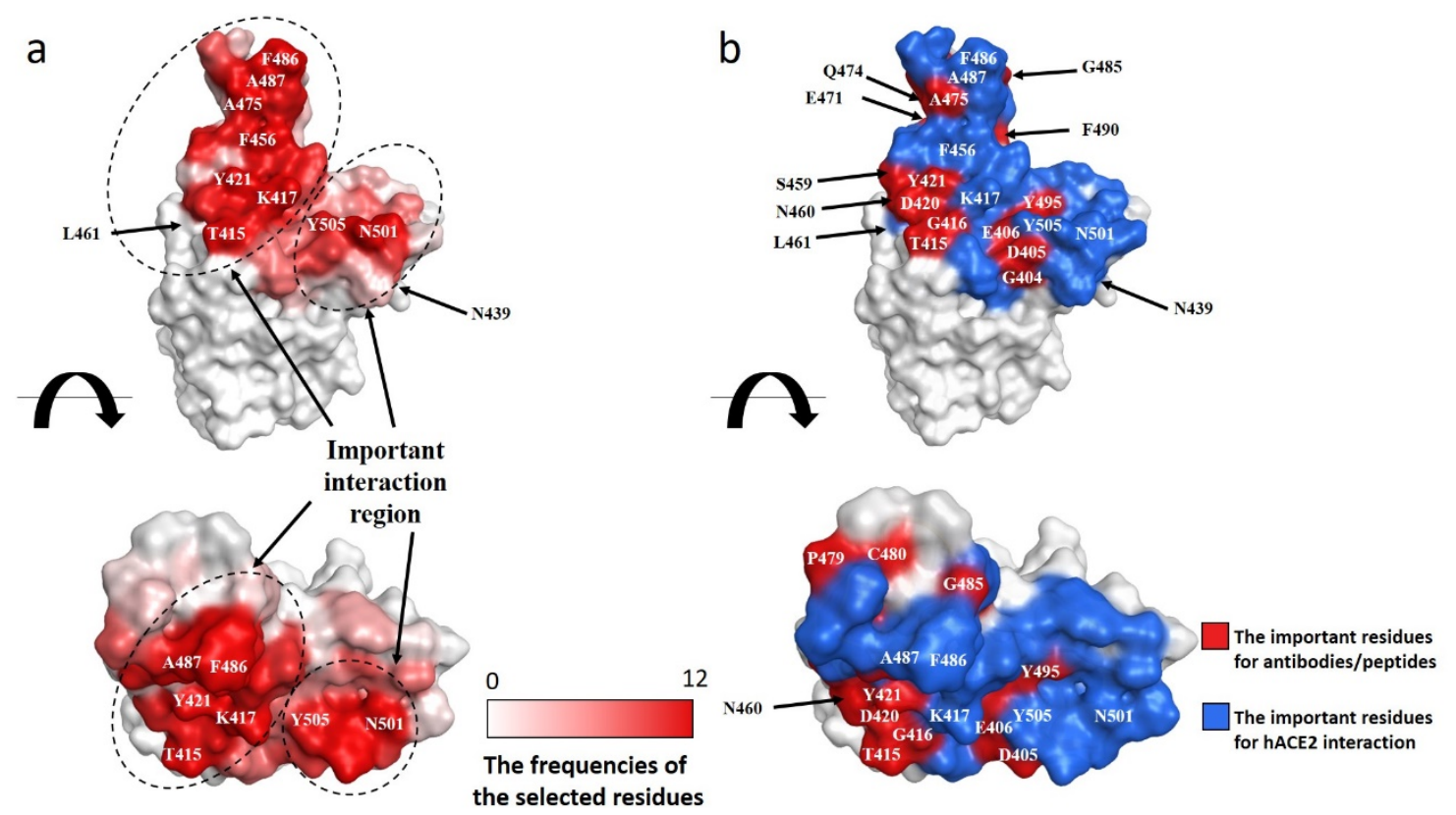

Figure 2. Important residues of the RBD for antibody/peptide binding. (a) The surface of RBD was colored according to the frequency of selected important residues in all the samples. Darker red indicates higher frequency. (b) Confirmation and comparison on important RBD residues found in this study and a previous report ${ }^{46}$ on the RBD-hACE2 interaction. Residues that are commonly important for hACE2 and antibodies/peptides in molecular recognition of RBD and residues that are important only for antibodies/peptides are shown in blue and red, respectively. For any ES, CT + mix, and DI components, the residues with interaction energy less than $-3 \mathrm{kcal} / \mathrm{mol}$ were considered important residues (refer to Table S4).

Fifty-two residues were identified as important residues in at least one of the structures, while nine residues (i.e., T415, K417, Y421, F456, A475, F486, N487, N501, and Y505) were commonly detected as key residues in all complexes. Furthermore, these residues consist of two important interaction regions (Figure 2a, Table S3, S4). To examine how much these key residues contribute to the RBD-antibody/peptide interactions, we calculated the correlation between the $\mathrm{pIC}_{50}$ and IFIE-sums obtained from only these nine 
residues. The result showed a slightly higher correlation $\left(R^{2}=0.555\right)$, indicating that these residues can sufficiently account for the RBD-antibody/peptide interactions (Figure 1d,

\section{Table S5).}

Next, the important residues in the RBD that were found in this study and those found in the previous report on the RBD-hACE2 interaction among SARS-CoV-2, SARS-CoV-2 chimera, and SARS-CoV ${ }^{46}$ were displayed and compared (Figure 2b). Most of the important RBD residues overlapped for RBD-antibodies/peptides and RBD-hACE2 interactions (blue-colored regions), except for two residues, N439 and L461. N439 and L461 were previously reported to be important for RBD-hACE2 interaction ${ }^{46}$, but they are located at the binding edge. Therefore, it can be said that the antibodies/peptides can inhibit hACE2 spatially via interaction with most of the important interaction points of hACE2 binding. Furthermore, regions outside the hACE2 binding sites are also used by antibodies/peptides as the epitopes (red-colored regions).

Finally, the interactions of the nine RBD residues with each amino acid residue of antibodies/peptides were analyzed using both IFIE and PIEDA values in detail. An analysis of the RBD and BD-629 Fab antibody complex (PDB ID: 7CH5) was shown because this antibody has the best activity value among the antibodies calculated in this 
study (Table S1). As the characteristics of the interactions at the interface between RBD and BD-629 Fab, and $\mathrm{XH} / \pi$ interactions ${ }^{35,44,46,56}$ with aromatic amino acids, such as tyrosine and phenilalanine, and hydrogen bonds with the oxygen atom of the main chain were frequently observed. Figure 3 shows the structure around the nine key residues in the RBD and BD-629 Fab complex. Tables S6 and S7 list the hydrogen bond and XH/ $\pi$ interaction energies and their characteristic distances between each fragment for nine residues by IFIE and PIEDA. Hydrogen bonds between side chains were also observed. The hydrogen bonds formed between RBD and BD-629 Fab could be categorized into four types based on Figure 3 and Table S6. The first was hydrogen bonds between the side chains of the neutral amino acid residues. The IFIEs between residues containing such hydrogen bonds were approximately -13 to $-14 \mathrm{kcal} / \mathrm{mol}$, specifically fragment pairs such as $\mathrm{T} 415_{\text {spike }}-Y_{58}(\mathrm{IFIE}=-13.0 \mathrm{kcal} / \mathrm{mol})$ and $\mathrm{N} 501_{\text {spike- }}-\mathrm{S} 30_{\mathrm{L}}(-14.0 \mathrm{kcal} / \mathrm{mol})$ from Figures 3a and $\mathbf{3 h}$, respectively. Second, the IFIEs between residues that contained a charged side chain on one of the amino acid residues that formed hydrogen bonds between the side chains were confirmed to be larger than the IFIEs of the first type because of the electrostatic interaction. Specifically, fragment pairs such as N487 spike-E26H $_{\text {(IFIE }=-25.8}$ $\mathrm{kcal} / \mathrm{mol})$ and $\mathrm{N} 487_{\text {spike- }}$ R97 $\mathrm{H}(\mathrm{IFIE}=-25.1 \mathrm{kcal} / \mathrm{mol})$ were formed, as shown in Figure 3g. Third, when both amino acid residues contained charged side chains, the electrostatic 
interaction of salt bridges as well as hydrogen bonds were much larger than the former two types, and the corresponding IFIE between $\mathrm{K} 417_{\text {spike-D }} 101_{\mathrm{H}}$ was $-153.1 \mathrm{kcal} / \mathrm{mol}$ (although the hydrogen bond between the K417 spike side chain and the oxygen atom of the main chain on $\mathrm{D} 101_{\mathrm{H}}$ was also included) as seen in Figure 3b. Finally, when hydrogen bonds were formed between the side chain and the oxygen atom of the main chain, the IFIEs were less than $-20 \mathrm{kcal} / \mathrm{mol}$, specifically, fragment pairs containing hydrogen bonds between the oxygen atom on the $\mathrm{F} 456_{\text {spike }}$ and the $\mathrm{Y} 33_{\mathrm{H}}$ side chain $(\mathrm{IFIE}=-23.7 \mathrm{kcal} / \mathrm{mol})$ (Figure 3d), between the oxygen atom on the Gly476 spike (assigned as the $A 475_{\text {spike }}$ fragment) and the $\mathrm{N} 32 \mathrm{H}$ side chain (IFIE $=-20.9 \mathrm{kcal} / \mathrm{mol}$ ) (Figure 3e), and between the $\mathrm{Y}_{505_{\text {spike }} \text { side chain and oxygen atom on the V29L }}($ IFIE $=-20.9 \mathrm{kcal} / \mathrm{mol})($ Figure 3i). On the other hand, many $\pi$-orbital interactions were observed around aromatic amino acid residues, which can be classified into two categories: the $\mathrm{OH} / \pi$ interaction and $\mathrm{CH} / \pi$ interactions. First, ES and DI values were similar between residues where the $\mathrm{OH} / \pi$ interaction was formed (see Table $\mathbf{S 7}$ for each energy component), specifically, the fragment pair such as $\mathrm{Y} 421_{\text {spike- }} \mathrm{Y} 33_{\mathrm{H}}$ (Figure 3c). On the other hand, in many cases, DI was the main component between residues where $\mathrm{CH} / \pi$ interactions were formed (Table S7). Specifically, fragment pairs such as $\mathrm{Y} 456_{\text {spike }}-\mathrm{Y}_{\mathrm{H}}, \mathrm{F} 486_{\text {spike }}-\mathrm{Y} 106_{\mathrm{H}}$, and $\mathrm{Y} 55_{\text {spike- }}$ F32 $\mathrm{H}$ (Figure 3d, 3f, and 3i, respectively). 
In the supporting information, we explained the binding mode around the key residues in detail. Here, the corresponding FMODB data regarding the detailed energy components between individual residues by IFIE/PIEDA can be referred to using the FMODB ID ${ }^{42}$ (Table S1).

As described above, we found that the nine key residues on the RBD strongly interact with the antibody residues regarded as the epitopes via various binding modes such as electrostatic interactions, hydrogen bonding, and $\pi$-orbital interactions (Figure 3). Here, the aromatic amino acids Y421, F456, F486, and Y505 were selected as key residues on the RBD, and as mentioned earlier, they interact with the residues on the antibody side by $\mathrm{XH} / \pi$ interactions. In FMO calculations, the $\mathrm{XH} / \pi$ interaction can be evaluated mainly by the DI term. However, it is difficult to accurately evaluate such $\mathrm{XH} / \pi$ interactions by molecular mechanics-based interaction energy analysis or structure-based geometry analysis with the classical force field ${ }^{44}$. This study accurately and quantitatively evaluated the $\mathrm{XH} / \pi$ interaction from the DI terms obtained by FMO calculations. We successfully detected aromatic amino acids that are important for the RBD-antibody/peptide interaction. This finding indicates the importance of specific aromatic amino acids on the 
RBD in the interaction of existing antibodies/peptides with RBDs and provides new insight into ACE2-blocking drug design.

In addition, K417, which was evaluated as a key residue in this study (Figure 3b), was mutated as $\mathrm{K} 417 \mathrm{~N}$ in the South African variant, 501.V2 variant ${ }^{9}$, and as $\mathrm{K} 417 \mathrm{~T}$ in the Brazilian variant, Lineage B. 1. 1. $248^{10}$. These mutations are predicted to lead to the loss of hydrogen bonds and $\mathrm{XH} / \pi$ interactions that $\mathrm{K} 417$ forms with residues on the antibody (Figure 3b). N501 (Figure 3h) is mutated as N501Y in these two variants as well as the British variant, VOC-202012/01 (also known as 501.V1 variant) ${ }^{8}$. The N501Y mutation is also predicted to lead to the loss of the hydrogen bond (ca $-13 \mathrm{kcal} / \mathrm{mol}$ ) that $\mathrm{N} 501$ forms with the residue on the antibody, while N501Y and its surrounding residue may form $\mathrm{XH} / \boldsymbol{\pi}$ interactions ${ }^{46}$ (Figure $\mathbf{3 h}$ ). Mutations in the RBD can cause conformational changes in the protein itself as well as substructural changes. When antibodies/peptides interact with the RBD, small changes in the distance between residues may significantly affect interaction strength. Recently, it has been reported that the South African and Brazilian variants can escape from existing neutralizing antibodies ${ }^{57,58}$. More attention should be paid to these highly infectious mutants. Further FMO calculations on the interaction between mutant RBDs and existing antibodies/peptides are needed. 

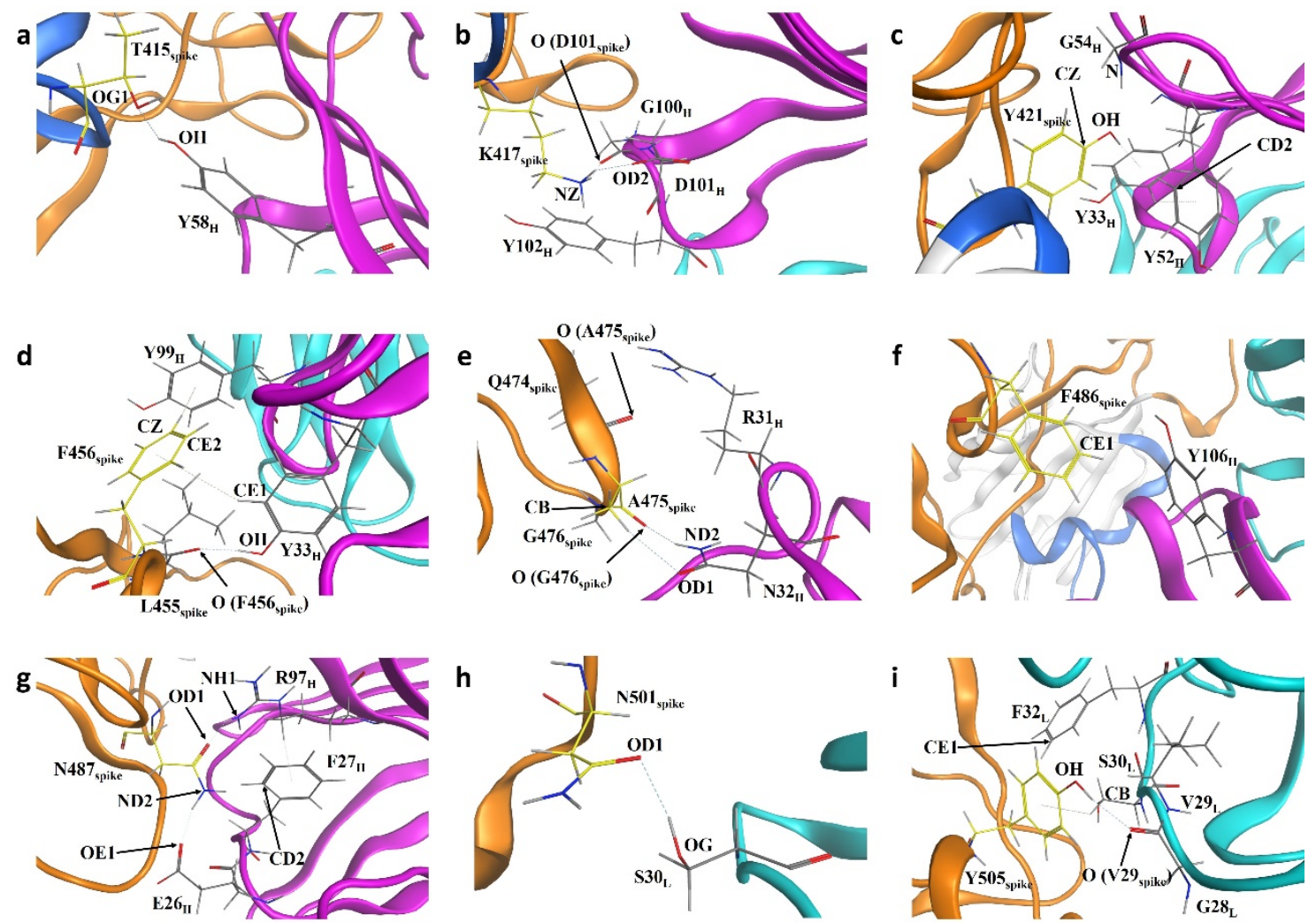

Figure 3. Structure around the nine key residues in the complex of RBD and BD-629 Fab; (a) T415; (b) K417; (c) Y421; (d) F456; (e) A475; (f) F486; (g) N487; (h) N501; (i) Y505. Region 1 on the RBD is shown in blue, Region 2 in orange, the heavy chain of BD-629 Fab in magenta, and the light chain in cyan. The amino acid residues on the RBD, heavy chain, and light chain are labeled with spike, H, and L in subscript, respectively.

In conclusion, this study analyzed the RBD-antibody/peptide interactions using FMO calculations. A fairly good correlation register between the calculated IFIE-sum and experimental $\mathrm{pIC}_{50}$ was confirmed. By further analyses, we extracted nine residues (T415, K417, Y421, F456, A475, F486, N487, N501, and Y505) in the crucial region of the RBD as critical for the binding of antibodies/peptides. These residues are also considered vital 
for S-protein-hACE2-binding. Detailed energy decompositions of IFIE by PIEDA around these residues showed that hydrogen bonds and electrostatic interactions, and $\pi$ orbital interactions are important. Notably, mutations in some of the critical residues extracted here have been reported to be highly infectious. Our results provide essential information for understanding SARS-CoV-2 and antibodies/peptide binding and may play roles in future antibody/antiviral drug design. 


\section{Supporting information}

Figure S1. Example of a computational model (PDB ID: 6XCM). Only monomeric RBDantibody/peptide was preserved for the FMO calculation.

Table S1. Structural information about each calculation model and interaction energies for RBD-antibodies/peptides.

Table S2. IFIE-sum of region 1 (R403-Y421), region 2 (RBM), and All (RBD) and the ratio of the IFIE-sum of region 1 or region 2 to the total IFIE-sum

Table S3. Relationship between residues on the RBD and the number of structures counted as important residues.

Table S4. PIEDA results of antibody/peptide-residues on the RBD (only region 1 (seq\# 403-421) and region 2 (RBM)).

Table S5. Interaction energies between the nine key residues on the RBD and antibodies/peptide.

Table S6. XH-Y hydrogen bonds between nine key residues on SARS-CoV-2 RBD and BD-629 Fab

Table S7. XH/ $\pi$ interactions between the nine key residues with SARS-CoV-2 RBD and BD-629 Fab.

\section{Notes}

The authors declare no competing financial interest.

\section{Acknowledgement}

This work was supported by JSPS KAKENHI Grant Number JP20K06987. Part of this research was conducted using the FMO drug design consortium (FMODD, https://fmodd.jp/). The FMO calculations were performed using the Oakforest-PACS supercomputer (project ID: hp200101). PIEDA calculations were performed using the MIZUHO/BioStation software package. This research was partially supported by the Platform Project for Supporting Drug Discovery and Life Science Research (Basis for 
Supporting Innovative Drug Discovery and Life Science Research (BINDS)) from AMED under Grant Number JP20am0101113. C.W. acknowledges the JST PRESTO Grant Number JPMJPR18GD, Japan. Y.S.T acknowledges Hirose International Scholarship Foundation research grant. We also thank Editage (www.editage.jp) for English language editing. 


\section{References}

(1) Huang, C.; Wang, Y.; Li, X.; Ren, L.; Zhao, J.; Hu, Y.; Zhang, L.; Fan, G.; Xu, J.; Gu, X.; Cheng, Z.; Yu, T.; Xia, J.; Wei, Y.; Wu, W.; Xie, X.; Yin, W.; Li, H.; Liu, M.; Xiao, Y.; Gao, H.; Guo, L.; Xie, J.; Wang, G.; Jiang, R.; Gao, Z.; Jin, Q.; Wang, J.; Cao, B. Clinical Features of Patients Infected with 2019 Novel Coronavirus in Wuhan, China. The Lancet 2020, 395 (10223), 497-506. https://doi.org/10.1016/S0140-6736(20)30183-5.

(2) Chan, J. F. W.; Yuan, S.; Kok, K. H.; To, K. K. W.; Chu, H.; Yang, J.; Xing, F.; Liu, J.; Yip, C. C. Y.; Poon, R. W. S.; Tsoi, H. W.; Lo, S. K. F.; Chan, K. H.; Poon, V. K. M.; Chan, W. M.; Ip, J. D.; Cai, J. P.; Cheng, V. C. C.; Chen, H.; Hui, C. K. M.; Yuen, K. Y. A Familial Cluster of Pneumonia Associated with the 2019 Novel Coronavirus Indicating Person-to-Person Transmission: A Study of a Family Cluster. The Lancet 2020, 395 (10223), 514-523. https://doi.org/10.1016/S01406736(20)30154-9.

(3) John Hapkins University. COVID-19 Dashboard by the Center for Systems Science. (accessed Feb 19, 2020).

(4) Polack, F. P.; Thomas, S. J.; Kitchin, N.; Absalon, J.; Gurtman, A.; Lockhart, S.; Perez, J. L.; Pérez Marc, G.; Moreira, E. D.; Zerbini, C.; Bailey, R.; Swanson, K. A.; Roychoudhury, S.; Koury, K.; Li, P.; Kalina, W. V.; Cooper, D.; Frenck, R. W.; Hammitt, L. L.; Türeci, Ö.; Nell, H.; Schaefer, A.; Ünal, S.; Tresnan, D. B.; Mather, S.; Dormitzer, P. R.; Şahin, U.; Jansen, K. U.; Gruber, W. C. Safety and Efficacy of the BNT162b2 MRNA Covid-19 Vaccine. New England Journal of Medicine 2020, 383 (27), 2603-2615. https://doi.org/10.1056/nejmoa2034577.

(5) Walsh, E. E.; Frenck, R. W.; Falsey, A. R.; Kitchin, N.; Absalon, J.; Gurtman, A.; Lockhart, S.; Neuzil, K.; Mulligan, M. J.; Bailey, R.; Swanson, K. A.; Li, P.; Koury, K.; Kalina, W.; Cooper, D.; Fontes-Garfias, C.; Shi, P.-Y.; Türeci, Ö.; Tompkins, K. R.; Lyke, K. E.; Raabe, V.; Dormitzer, P. R.; Jansen, K. U.; Şahin, U.; Gruber, W. C. Safety and Immunogenicity of Two RNA-Based Covid-19 Vaccine Candidates. New England Journal of Medicine 2020, 383 (25), 2439-2450. https://doi.org/10.1056/nejmoa2027906.

(6) Jackson, L. A.; Anderson, E. J.; Rouphael, N. G.; Roberts, P. C.; Makhene, M.; Coler, R. N.; McCullough, M. P.; Chappell, J. D.; Denison, M. R.; Stevens, L. J.; 
Pruijssers, A. J.; McDermott, A.; Flach, B.; Doria-Rose, N. A.; Corbett, K. S.; Morabito, K. M.; O’Dell, S.; Schmidt, S. D.; Swanson, P. A.; Padilla, M.; Mascola, J. R.; Neuzil, K. M.; Bennett, H.; Sun, W.; Peters, E.; Makowski, M.; Albert, J.; Cross, K.; Buchanan, W.; Pikaart-Tautges, R.; Ledgerwood, J. E.; Graham, B. S.; Beigel, J. H. An MRNA Vaccine against SARS-CoV-2 — Preliminary Report. New England Journal of Medicine 2020, 383 (20), 1920-1931. https://doi.org/10.1056/nejmoa2022483.

(7) Baden, L. R.; El Sahly, H. M.; Essink, B.; Kotloff, K.; Frey, S.; Novak, R.; Diemert, D.; Spector, S. A.; Rouphael, N.; Creech, C. B.; McGettigan, J.; Khetan, S.; Segall, N.; Solis, J.; Brosz, A.; Fierro, C.; Schwartz, H.; Neuzil, K.; Corey, L.; Gilbert, P.; Janes, H.; Follmann, D.; Marovich, M.; Mascola, J.; Polakowski, L.; Ledgerwood, J.; Graham, B. S.; Bennett, H.; Pajon, R.; Knightly, C.; Leav, B.; Deng, W.; Zhou, H.; Han, S.; Ivarsson, M.; Miller, J.; Zaks, T. Efficacy and Safety of the mRNA1273 SARS-CoV-2 Vaccine. New England Journal of Medicine 2020, 1-14. https://doi.org/10.1056/nejmoa2035389.

(8) Kirby, T. New Variant of SARS-CoV-2 in UK Causes Surge of COVID-19. The Lancet Respiratory 2021, https://doi.org/10.1016/S2213-2600(21)00005-9.

(9) Tegally, H.; Wilkinson, E.; Giovanetti, M.; Iranzadeh, A.; Fonseca, V.; Giandhari, J.; Doolabh, D.; Pillay, S.; San, E. J.; Wibmer, K.; Sewell, B. T.; Lourenço, J.; Carlos, L.; Alcantara, J.; Kosakovsky, S. L.; Weaver, S.; Martin, D.; Lessells, R. J.; Bhiman, J. N.; Williamson, C.; De Oliveira, T. Emergence and Rapid Spread of a New Severe Acute Respiratory Syndrome-Related Coronavirus 2 (SARS-CoV2) Lineage with Multiple Spike Mutations in South Africa. Arghavan AlisoltaniDehkordi 2020, https://doi.org/10.1101/2020.12.21.20248640.

(10) Voloch, C. M.; Jr, R. da S. F.; Almeida, L. G. P. de; Cardoso, C. C.; Brustolini, O. J.; Gerber, A. L.; Guimarães, A. P. de C.; Mariani, D.; Costa, R. M. da; Jr, O. C. F.; LNCC-Workgroup, C.-U. W.; Frauches, A. C. C. T. S.; Mello, C. M. B. de; Galliez, R. M.; Tanuri, D. S. F. T. M. P. P. C. A.; Vasconcelos, A. T. R. de. Genomic Characterization of a Novel SARS-CoV-2 Lineage from Rio de Janeiro, Brazil. medRxiv 2020. https://doi.org/10.1101/2020.12.23.20248598.

(11) Masters, P. S. The Molecular Biology of Coronaviruses. Advances in Virus Research 2006, 65 (06), 193-292. https://doi.org/10.1016/S0065-3527(06)660053. 
(12) Li, F.; Li, W.; Farzan, M.; Harrison, S. C. Structural Biology: Structure of SARS Coronavirus Spike Receptor-Binding Domain Complexed with Receptor. Science 2005, 309 (5742), 1864-1868. https://doi.org/10.1126/science.1116480.

(13) Walls, A. C.; Park, Y. J.; Tortorici, M. A.; Wall, A.; McGuire, A. T.; Veesler, D. Structure, Function, and Antigenicity of the SARS-CoV-2 Spike Glycoprotein. Cell 2020, 181 (2), 281-292.e6. https://doi.org/10.1016/j.cell.2020.02.058.

(14) Wrapp, D.; Wang, N.; Corbett, K. S.; Goldsmith, J. A.; Hsieh, C. L.; Abiona, O.; Graham, B. S.; McLellan, J. S. Cryo-EM Structure of the 2019-NCoV Spike in the Prefusion Conformation. Science 2020, 367 (6483), 1260-1263. https://doi.org/10.1126/science.aax0902.

(15) Ou, X.; Liu, Y.; Lei, X.; Li, P.; Mi, D.; Ren, L.; Guo, L.; Guo, R.; Chen, T.; Hu, J.; Xiang, Z.; Mu, Z.; Chen, X.; Chen, J.; Hu, K.; Jin, Q.; Wang, J.; Qian, Z. Characterization of Spike Glycoprotein of SARS-CoV-2 on Virus Entry and Its Immune Cross-Reactivity with SARS-CoV. Nature Communications 2020, 11 (1). https://doi.org/10.1038/s41467-020-15562-9.

(16) Hoffmann, M.; Kleine-Weber, H.; Schroeder, S.; Krüger, N.; Herrler, T.; Erichsen, S.; Schiergens, T. S.; Herrler, G.; Wu, N. H.; Nitsche, A.; Müller, M. A.; Drosten, C.; Pöhlmann, S. SARS-CoV-2 Cell Entry Depends on ACE2 and TMPRSS2 and Is Blocked by a Clinically Proven Protease Inhibitor. Cell 2020, 271-280. https://doi.org/10.1016/j.cell.2020.02.052.

(17) Hurlburt, N. K.; Seydoux, E.; Wan, Y. H.; Edara, V. V.; Stuart, A. B.; Feng, J.; Suthar, M. S.; McGuire, A. T.; Stamatatos, L.; Pancera, M. Structural Basis for Potent Neutralization of SARS-CoV-2 and Role of Antibody Affinity Maturation. Nature Communications 2020, 11 (1). https://doi.org/10.1038/s41467-020-192319.

(18) Yuan, M.; Liu, H.; Wu, N. C.; Lee, C. C. D.; Zhu, X.; Zhao, F.; Huang, D.; Yu, W.; Hua, Y.; Tien, H.; Rogers, T. F.; Landais, E.; Sok, D.; Jardine, J. G.; Burton, D. R.; Wilson, I. A. Structural Basis of a Shared Antibody Response to SARSCoV-2. Science 2020, $369 \quad$ (6507), 1119-1123. https://doi.org/10.1126/science.abd2321.

(19) Thomas, F. R.; Fangzhu, Z.; Deli, H.; Nathan, B.; Alison, B. Isolation of Potent SARS-CoV-2 Neutralizing Antibodies and Protection from Disease in a Small 
Animal Model. Science 2020, 963 (August), 956-963. https://doi.org/10.1126/science.abc7520

(20) Shi, R.; Shan, C.; Duan, X.; Chen, Z.; Liu, P.; Song, J.; Song, T.; Bi, X.; Han, C.; Wu, L.; Gao, G.; Hu, X.; Zhang, Y.; Tong, Z.; Huang, W.; Liu, W. J.; Wu, G.; Zhang, B.; Wang, L.; Qi, J.; Feng, H.; Wang, F. S.; Wang, Q.; Gao, G. F.; Yuan, Z.; Yan, J. A Human Neutralizing Antibody Targets the Receptor-Binding Site of SARS-CoV-2. Nature 2020, 584 (7819), 120-124. https://doi.org/10.1038/s41586$020-2381-y$.

(21) Brouwer, P. J. M.; Caniels, T. G.; van der Straten, K.; Snitselaar, J. L.; Aldon, Y.; Bangaru, S.; Torres, J. L.; Okba, N. M. A.; Claireaux, M.; Kerster, G.; Bentlage, A. E. H.; van Haaren, M. M.; Guerra, D.; Burger, J. A.; Schermer, E. E.; Verheul, K. D.; van der Velde, N.; van der Kooi, A.; van Schooten, J.; van Breemen, M. J.; Bij1, T. P. L.; Sliepen, K.; Aartse, A.; Derking, R.; Bontjer, I.; Kootstra, N. A.; Joost Wiersinga, W.; Vidarsson, G.; Haagmans, B. L.; Ward, A. B.; de Bree, G. J.; Sanders, R. W.; van Gils, M. J. Potent Neutralizing Antibodies from COVID-19 Patients Define Multiple Targets of Vulnerability. Science 2020, 369 (6504), 643650. https://doi.org/10.1126/science.abc5902.

(22) Barnes, C. O.; Jette, C. A.; Abernathy, M. E.; Dam, K. M. A.; Esswein, S. R.; Gristick, H. B.; Malyutin, A. G.; Sharaf, N. G.; Huey-Tubman, K. E.; Lee, Y. E.; Robbiani, D. F.; Nussenzweig, M. C.; West, A. P.; Bjorkman, P. J. SARS-CoV-2 Neutralizing Antibody Structures Inform Therapeutic Strategies. Nature 2020, 588 (7839), 682-687. https://doi.org/10.1038/s41586-020-2852-1.

(23) Barnes, C. O.; West, A. P.; Huey-Tubman, K. E.; Hoffmann, M. A. G.; Sharaf, N. G.; Hoffman, P. R.; Koranda, N.; Gristick, H. B.; Gaebler, C.; Muecksch, F.; Lorenzi, J. C. C.; Finkin, S.; Hägglöf, T.; Hurley, A.; Millard, K. G.; Weisblum, Y.; Schmidt, F.; Hatziioannou, T.; Bieniasz, P. D.; Caskey, M.; Robbiani, D. F.; Nussenzweig, M. C.; Bjorkman, P. J. Structures of Human Antibodies Bound to SARS-CoV-2 Spike Reveal Common Epitopes and Recurrent Features of $\begin{array}{lllll}\text { Antibodies. } & \text { Cell } & \text { 2020, } & 182 & \text { (4), }\end{array}$ https://doi.org/10.1016/j.cell.2020.06.025.

(24) Wu, N. C.; Yuan, M.; Liu, H.; Lee, C. C. D.; Zhu, X.; Bangaru, S.; Torres, J. L.; Caniels, T. G.; Brouwer, P. J. M.; van Gils, M. J.; Sanders, R. W.; Ward, A. B.; Wilson, I. A. An Alternative Binding Mode of IGHV3-53 Antibodies to the SARS- 
CoV-2 Receptor Binding Domain. Cell Reports 2020, 33 (3), 108274. https://doi.org/10.1016/j.celrep.2020.108274.

(25) Kreye, J.; Reincke, S. M.; Kornau, H. C.; Sánchez-Sendin, E.; Corman, V. M.; Liu, H.; Yuan, M.; Wu, N. C.; Zhu, X.; Lee, C. C. D.; Trimpert, J.; Höltje, M.; Dietert, K.; Stöffler, L.; von Wardenburg, N.; van Hoof, S.; Homeyer, M. A.; Hoffmann, J.; Abdelgawad, A.; Gruber, A. D.; Bertzbach, L. D.; Vladimirova, D.; Li, L. Y.; Barthel, P. C.; Skriner, K.; Hocke, A. C.; Hippenstiel, S.; Witzenrath, M.; Suttorp, N.; Kurth, F.; Franke, C.; Endres, M.; Schmitz, D.; Jeworowski, L. M.; Richter, A.; Schmidt, M. L.; Schwarz, T.; Müller, M. A.; Drosten, C.; Wendisch, D.; Sander, L. E.; Osterrieder, N.; Wilson, I. A.; Prüss, H. A Therapeutic Non-Self-Reactive SARS-CoV-2 Antibody Protects from Lung Pathology in a COVID-19 Hamster Model. Cell 2020, $183 \quad$ (4), 1058-1069.e19. https://doi.org/10.1016/j.cell.2020.09.049.

(26) Du, S.; Cao, Y.; Zhu, Q.; Yu, P.; Qi, F.; Wang, G.; Du, X.; Bao, L.; Deng, W.; Zhu, H.; Liu, J.; Nie, J.; Zheng, Y.; Liang, H.; Liu, R.; Gong, S.; Xu, H.; Yisimayi, A.; Lv, Q.; Wang, B.; He, R.; Han, Y.; Zhao, W.; Bai, Y.; Qu, Y.; Gao, X.; Ji, C.; Wang, Q.; Gao, N.; Huang, W.; Wang, Y.; Xie, X. S.; Su, X. dong; Xiao, J.; Qin, C. Structurally Resolved SARS-CoV-2 Antibody Shows High Efficacy in Severely Infected Hamsters and Provides a Potent Cocktail Pairing Strategy. Cell 2020, 183 (4), 1013-1023.e13. https://doi.org/10.1016/j.cell.2020.09.035.

(27) Cao, L.; Goreshnik, I.; Coventry, B.; Case, J. B.; Miller, L.; Kozodoy, L.; Chen, R. E.; Carter, L.; Walls, A. C.; Park, Y. J.; Strauch, E. M.; Stewart, L.; Diamond, M. S.; Veesler, D.; Baker, D. De Novo Design of Picomolar SARS-CoV-2 Miniprotein Inhibitors. $\quad$ Science 2020, $370 \quad$ (6515), $426-431$. https://doi.org/10.1126/science.abd9909.

(28) Linsky, T. W.; Vergara, R.; Codina, N.; Nelson, J. W.; Walker, M. J.; Su, W.; Barnes, C. O.; Hsiang, T. Y.; Esser-Nobis, K.; Yu, K.; Reneer, Z. B.; Hou, Y. J.; Priya, T.; Mitsumoto, M.; Pong, A.; Lau, U. Y.; Mason, M. L.; Chen, J.; Chen, A.; Berrocal, T.; Peng, H.; Clairmont, N. S.; Castellanos, J.; Lin, Y. R.; JosephsonDay, A.; Baric, R. S.; Fuller, D. H.; Walkey, C. D.; Ross, T. M.; Swanson, R.; Bjorkman, P. J.; Gale, M.; Blancas-Mejia, L. M.; Yen, H. L.; Silva, D. A. De Novo Design of Potent and Resilient HACE2 Decoys to Neutralize SARS-CoV-2. Science 2020, 370 (6521), 1208-1214. https://doi.org/10.1126/science.abe0075. 
(29) Kitaura, K.; Ikeo, E.; Asada, T.; Nakano, T.; Uebayasi, M. Fragment Molecular Orbital Method: An Approximate Computational Method for Large Molecules. Chemical Physics Letters 1999, $313 \quad$ (3-4), 701-706. https://doi.org/10.1016/S0009-2614(99)00874-X.

(30) Fedorov, D. G.; Nagata, T.; Kitaura, K. Exploring Chemistry with the Fragment Molecular Orbital Method. Physical Chemistry Chemical Physics 2012, 14 (21), 7562-7577. https://doi.org/10.1039/c2cp23784a.

(31) Tanaka, S.; Mochizuki, Y.; Komeiji, Y.; Okiyama, Y.; Fukuzawa, K. ElectronCorrelated Fragment-Molecular-Orbital Calculations for Biomolecular and Nano Systems. Physical Chemistry Chemical Physics 2014, 16 (22), 10310-10344. https://doi.org/10.1039/c4cp00316k.

(32) Amari, S.; Aizawa, M.; Zhang, J.; Fukuzawa, K.; Mochizuki, Y.; Iwasawa, Y.; Nakata, K.; Chuman, H.; Nakano, T. VISCANA: Visualized Cluster Analysis of Protein - Ligand Interaction Based on the Ab Initio Fragment Molecular Orbital Method for Virtual Ligand Screening. Journal of Chemical Information and Modeling 2006, 46 (1), 221-230. https://doi.org/10.1021/ci050262q.

(33) Fukuzawa, K.; Mochizuki, Y.; Tanaka, S.; Kitaura, K.; Nakano, T. Erratum: Molecular Interactions between Estrogen Receptor and Its Ligand Studied by the Ab Initio Fragment Molecular Orbital Method (Journal of Physical Chemistry B (2006) 110B). Journal of Physical Chemistry B 2006, 110 (47), 24276. https://doi.org/10.1021/jp065705n.

(34) Iwata, T.; Fukuzawa, K.; Nakajima, K.; Aida-Hyugaji, S.; Mochizuki, Y.; Watanabe, H.; Tanaka, S. Theoretical Analysis of Binding Specificity of Influenza Viral Hemagglutinin to Avian and Human Receptors Based on the Fragment Molecular Orbital Method. Computational Biology and Chemistry 2008, 32 (3), 198-211. https://doi.org/10.1016/j.compbiolchem.2008.03.006.

(35) Ozawa, T.; Tsuji, E.; Ozawa, M.; Handa, C.; Mukaiyama, H.; Nishimura, T.; Kobayashi, S.; Okazaki, K. The Importance of $\mathrm{CH} / \pi$ Hydrogen Bonds in Rational Drug Design: An Ab Initio Fragment Molecular Orbital Study to LeukocyteSpecific Protein Tyrosine (LCK) Kinase. Bioorganic and Medicinal Chemistry 2008, 16 (24), 10311-10318. https://doi.org/10.1016/j.bmc.2008.10.041. 
(36) Takematsu, K.; Fukuzawa, K.; Omagari, K.; Nakajima, S.; Nakajima, K.; Mochizuki, Y.; Nakano, T.; Watanabe, H.; Tanaka, S. Possibility of Mutation Prediction of Influenza Hemagglutinin by Combination of Hemadsorption Experiment and Quantum Chemical Calculation for Antibody Binding. Journal of $\begin{array}{lllll}\text { Physical Chemistry } & B & \mathbf{2 0 0 9}, & 113 & \text { (15), }\end{array}$ https://doi.org/10.1021/jp810997c.

(37) Hitaoka, S.; Harada, M.; Yoshida, T.; Chuman, H. Correlation Analyses on Binding Affinity of Sialic Acid Analogues with Influenza Virus Neuraminidase-1 Using Ab Initio MO Calculations on Their Complex Structures. Journal of Chemical Information and Modeling 2010, 50 (10), 1796-1805. https://doi.org/10.1021/ci100225b.

(38) Xu, F.; Tanaka, S.; Watanabe, H.; Shimane, Y.; Iwasawa, M.; Ohishi, K.; Maruyama, T. Computational Analysis of the Interaction Energies between Amino Acid Residues of the Measles Virus Hemagglutinin and Its Receptors. Viruses 2018, 10 (5), 1-18. https://doi.org/10.3390/v10050236.

(39) Okiyama, Y.; Watanabe, C.; Fukuzawa, K.; Mochizuki, Y.; Nakano, T.; Tanaka, S. Fragment Molecular Orbital Calculations with Implicit Solvent Based on the Poisson-Boltzmann Equation: II. Protein and Its Ligand-Binding System Studies. Journal of Physical Chemistry B 2019, 123 (5), 957-973. https://doi.org/10.1021/acs.jpcb.8b09326.

(40) Kato, K.; Honma, T.; Fukuzawa, K. Intermolecular Interaction among Remdesivir, RNA and RNA-Dependent RNA Polymerase of SARS-CoV-2 Analyzed by Fragment Molecular Orbital Calculation. Journal of Molecular Graphics and Modelling 2020, 100, 107695. https://doi.org/10.1016/j.jmgm.2020.107695.

(41) Hatada, R.; Okuwaki, K.; Mochizuki, Y.; Handa, Y.; Fukuzawa, K.; Komeiji, Y.; Okiyama, Y.; Tanaka, S. Fragment Molecular Orbital Based Interaction Analyses on COVID-19 Main Protease - Inhibitor N3 Complex (PDB ID: 6LU7). Journal of Chemical Information and Modeling 2020, 60 (7), 3593-3602. https://doi.org/10.1021/acs.jcim.0c00283.

(42) FMO DATABASE (FMODB) https://drugdesign.riken.jp/FMODB/ (accessed Dec 7, 2020). 
(43) Watanabe, C.; Watanabe, H.; Okiyama, Y.; Takaya, D.; Fukuzawa, K.; Tanaka, S.; Honma, T. Development of an Automated Fragment Molecular Orbital (FMO) Calculation Protocol toward Construction of Quantum Mechanical Calculation Database for Large Biomolecules . CBIJ 2019, 19 (0), 5-18. https://doi.org/10.1273/cbij.19.5.

(44) Takaya, D.; Watanabe, C.; Nagase, S.; Kamisaka, K.; Okiyama, Y.; Moriwaki, H.; Yuki, H.; Sato, T.; Kurita, N.; Yagi, Y.; Takagi, T.; Kawashita, N.; Takaba, K.; Ozawa, T.; Takimoto-Kamimura, M.; Tanaka, S.; Fukuzawa, K.; Honma, T. FMODB: The World's First Database of Quantum Mechanical Calculations for Biomacromolecules Based on the Fragment Molecular Orbital Method. J. Chem. Inf. Model. 2021, acs.jcim.0c01062. https://doi.org/10.1021/acs.jcim.0c01062.

(45) Lim, H.; Baek, A.; Kim, J.; Kim, M. S.; Liu, J.; Nam, K. Y.; Yoon, J. H.; No, K. T. Hot Spot Profiles of SARS-CoV-2 and Human ACE2 Receptor Protein Protein Interaction Obtained by Density Functional Tight Binding Fragment Molecular Orbital Method. Scientific Reports 2020, $10 \quad$ (1), 1-8. https://doi.org/10.1038/s41598-020-73820-8.

(46) Watanabe, C., Okiyama, Y., Tanaka, S., Fukuzawa, K. \& Honma, T. Molecular Recognition of SARS-CoV-2 Spike Glycoprotein: Quantum Chemical Hot Spot and Epitope Analyses (preprint). ChemRxiv (2020).

(47) Akisawa, K.; Hatada, R.; Okuwaki, K.; Mochizuki, Y.; Fukuzawa, K.; Komeiji, Y.; Tanaka, S. Interaction Analyses on SARS-CoV-2 Spike Protein Based on Fragment Molecular Orbital Calculations. RSC Adv., 2021, 11, 3272-3279. DOI: 10.1039/D0RA09555A.

(48) Mochizuki, Y.; Koikegami, S.; Nakano, T.; Amari, S.; Kitaura, K. Large Scale MP2 Calculations with Fragment Molecular Orbital Scheme. Chemical Physics Letters 2004, 396 (4-6), 473-479. https://doi.org/10.1016/j.cplett.2004.08.082.

(49) Mochizuki, Y.; Nakano, T.; Koikegami, S.; Tanimori, S.; Abe, Y.; Nagashima, U.; Kitaura, K. A Parallelized Integral-Direct Second-Order Møller-Plesset Perturbation Theory Method with a Fragment Molecular Orbital Scheme. Theoretical Chemistry Accounts 2004, 112 (5-6), 442-452. https://doi.org/10.1007/s00214-004-0602-3. 
(50) Nakano, T.; Mochizuki, Y.; Fukuzawa, K.; Amari, S.; Tanaka, S. CHAPTER 2 Developments and Applications of ABINIT-MP Software Based on the Fragment Molecular Orbital Method. In Modern Methods for Theoretical Physical Chemistry of Biopolymers; Starikov, E. B., Lewis, J. P., Tanaka, S., Eds.; Elsevier Science: Amsterdam, 2006; pp 39-52. https://doi.org/10.1016/B978-044452220-7/50066-6.

(51) Tanaka, S.; Mochizuki, Y.; Komeiji, Y.; Okiyama, Y.; Fukuzawa, K. ElectronCorrelated Fragment-Molecular-Orbital Calculations for Biomolecular and Nano Systems. Phys. Chem. Chem. Phys. 2014, 16 (22), 10310-10344. https://doi.org/10.1039/C4CP00316K.

(52) Recent Advances of the Fragment Molecular Orbital Method: Enhanced Performance and Applicability; Mochizuki, Y., Tanaka, S., Fukuzawa, K., Eds.; Springer Singapore, 2021. https://doi.org/10.1007/978-981-15-9235-5.

(53) Federov, D. G.; Kitaura, K. Pair Interaction Energy Decomposition Analysis. Journal of computational chemistry 2007, 28 (1), 222-237. https://doi.org/10.1002/jcc.20496.

(54) Fedorov, D. G.; Kitaura, K. Energy Decomposition Analysis in Solution Based on the Fragment Molecular Orbital Method. Journal of Physical Chemistry A 2012, 116 (1), 704-719. https://doi.org/10.1021/jp209579w.

(55) Lan, J.; Ge, J.; Yu, J.; Shan, S.; Zhou, H.; Fan, S.; Zhang, Q.; Shi, X.; Wang, Q.; Zhang, L.; Wang, X. Structure of the SARS-CoV-2 Spike Receptor-Binding Domain Bound to the ACE2 Receptor. Nature 2020, 581 (7807), 215-220. https://doi.org/10.1038/s41586-020-2180-5.

(56) Nishio, M.; Umezawa, Y.; Fantini, J.; Weiss, M. S.; Chakrabarti, P. CH- $\pi$ Hydrogen Bonds in Biological Macromolecules. Phys. Chem. Chem. Phys. 2014, 16 (25), 12648-12683. https://doi.org/10.1039/c4cp00099d.

(57) Wibmer, C. K.; Ayres, F.; Hermanus, T.; Madzivhandila, M. SARS-CoV-2 501Y . V2 Escapes Neutralization by South African COVID-19 Donor Plasma. bioRxiv 2021.

(58) Kymie, C.; Nonaka, V.; Franco, M. M.; Gräf, T.; Verena, A.; Mendes, A.; Santana De Aguiar, R.; Giovanetti, M.; Solano, B.; Souza, F.; Souza, B. S. F. Genomic 
Evidence of a Sars-Cov-2 Reinfection Case With E484K Spike Mutation in Brazil. Preprints.Org 2021, No. 6. https://doi.org/10.20944/preprints202101.0132.v1. 